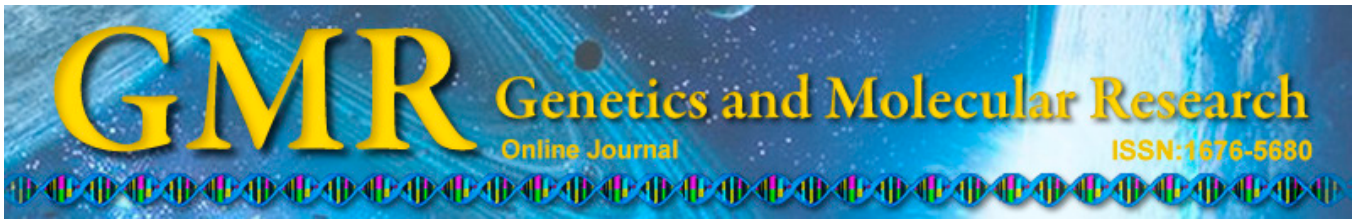

\title{
Construction and analysis of a suppression subtractive hybridization library of regeneration-related genes in soybean
}

\author{
J. Sun ${ }^{1,2}$, J. Li ${ }^{1}$, M. Liu', B.B. Zhang', D.M. Li', M. Wang', C. Zhang', \\ W.B. $\mathrm{Li}^{1}, \mathrm{~A} . \mathrm{Y} . \mathrm{Su}^{3}$ and X.X. $\mathrm{Wu}^{1}$ \\ ${ }^{1}$ Key Laboratory of Soybean Biology of Chinese Ministry of Education, \\ College of Agronomy, Northeast Agricultural University, Harbin, China \\ ${ }^{2}$ Berries Research Institute, Heilongjiang Academy of Agricultural Sciences, \\ Suiling, Heilongjiang, China \\ ${ }^{3}$ College of Resource and Environment, Northeast Agricultural University, \\ Harbin, China \\ Corresponding authors: X.X. Wu / A.Y. Su \\ E-mail: xxwu2013@126.com / unu123@163.com
}

Genet. Mol. Res. 14 (1): 763-773 (2015)

Received January 10, 2014

Accepted November 28, 2014

Published January 30, 2015

DOI http://dx.doi.org/10.4238/2015.January.30.20

\begin{abstract}
The development of a genetic transformation system is needed to address the problem of the low efficiency associated with soybean regeneration. To contribute to the enhancement of the soybean regenerative capacity, we explored the developmental mechanisms of soybean regeneration at the molecular level using a suppression subtractive hybridization cDNA library constructed from cotyledonary nodes of soybean cultivar DN50. A total of 918 positive clones were identified and screened, with most inserted fragments ranging from 100 to $750 \mathrm{bp}$. Of these, 411 differentially expressed functional expressed sequence tags were identified and annotated based on their similarity to orthologs and paralogs detected in GenBank using the nucleotide and translated nucleotide Basic Local Alignment Search Tools. Functional analysis revealed that the associated genes were involved in signal
\end{abstract}


transduction, synthesis, and metabolism of macromolecules, glucose and protein synthesis and metabolism, light and leaf morphogenesis, regulation of apoptosis, cell defense, cell wall differentiation, and a variety of hormone and cytokinin-mediated signaling pathways. The information uncovered in our study should serve as a foundation for the establishment of an efficient and stable genetic transformation system for soybean regeneration.

Key words: Soybean; Suppression subtractive hybridization (SSH); cDNA library; Soybean regeneration

\section{INTRODUCTION}

Following the success of the Agrobacterium-mediated DNA transfer method (Hinchee et al., 1988) and particle gun technology (McCabe et al., 1988), no further breakthroughs have occurred in the production of transgenic soybean (Glycine max [L.] Merrill.). The low frequency and poor reproducibility of soybean regeneration are recognized as a bottleneck in the transformation of this important crop species. Research on soybean regeneration systems has focused mainly on aspects such as explant type, genotype, hormone type, and culture conditions. Few studies have investigated the molecular basis of regeneration systems, especially the underlying mechanisms and the genes playing roles in the regeneration process. If the expression of soybean regeneration genes can be regulated, then the problem of soybean's low regeneration ability could possibly be addressed.

In recent years, somatic embryo and cotyledon node regeneration-related genes have been frequently studied. Li and Komatsu (2000) characterized the CRO1 gene, which is involved in the regeneration process in rice cell-suspension cultures. In petunia, Zubko et al. (2002) identified the regeneration candidate gene Sho that increases the expression of isopentenyl transferase, a key enzyme in the cytokinin pathway. Komatsuda et al. (1993) obtained the shoot regeneration-related gene $S h d 1$ through quantitative trait locus mapping, and Zakizadeh et al. (2010) isolated the candidate regeneration gene SERK from rose.

In Arabidopsis, the regulation of the regeneration process involves a large number of genes. For example, the overexpression of the ESR1 gene, which was detected in Arabidopsis by Banno et al. (2001), can induce the start of shoot regeneration, and the ESR2 gene, which was cloned by Ikeda et al. (2006), can promote regeneration. ESR1 and ESR2 both have an AP2/EREBP transcription factor domain. Ikeda et al. (2006) reported that ESR2 controls Arabidopsis regeneration by regulating the $C U C 1$ gene. In addition, Leibfried et al. (2005) found that the WUSCHEL gene family can control somatic embryogenesis by regulating cytokininresponsive elements.

Suppression subtractive hybridization (SSH) is a powerful and widely used approach to generate subtracted cDNA libraries to identify differentially expressed genes. SSH has many outstanding advantages, such as a low false-positive rate, high sensitivity, a short screening cycle, and high efficiency. Using SSH, Low et al. (2001) identified the regeneration candidate gene PKSF1 in Paulownia kawakamii. This gene encodes a leucine zipper transcription factor that promotes callus formation. We found that the cotyledon node of DN50 induced the cytokinin 6-benzyladenine (6-BA), and we used SSH to identify differentially expressed genes. Functional analysis of these genes revealed their roles in the studied regeneration system, 
opening the door to further research into the molecular basis of soybean regeneration.

\section{MATERIAL AND METHODS}

\section{Material}

The soybean variety DN50, which has a high regeneration rate, was provided by the Soybean Institute, Northeast Agricultural University, Harbin, China. After chlorine sterilization, seeds were inoculated with the hilum down onto germination medium [4.43 g Murashige and Skoog basal medium (MS), 3\% sucrose, and 0.7\% agar, $\mathrm{pH} 5.8$ ] and cultured for 5-7 days at $25^{\circ} \mathrm{C}$ under $250 \mu \mathrm{mol} \cdot \mathrm{m}^{-2} \cdot \mathrm{s}^{-1}$ white-light illumination and long-day conditions $(16 / 8$-h light/ dark photoperiod). The seed coat was then removed, and most of the hypocotyl was excised, leaving only 3-5 mm of the hypocotyl on the cotyledon. The 2 cotyledons were separated vertically along the hypocotyl midline, and the terminal and axillary buds were removed to obtain the cotyledon explants. Some of the cotyledon explants were inoculated into liquid medium containing $4.43 \mathrm{~g} \mathrm{MS}, 2 \mathrm{mg} / \mathrm{L}$ 6-BA, and 3\% sucrose, $\mathrm{pH}$ 5.8, with samples taken 1, 2, 3, 4, 5, $6,7,8,9$, and $10 \mathrm{~h}$ later for use as SSH tester samples. The remaining cotyledon explants were inoculated into liquid medium lacking 6-BA, and samples were taken 1, 2, 3, 4, 5, 6, 7, 8, 9, and $10 \mathrm{~h}$ later as SSH driver samples. All samples were frozen in liquid nitrogen and stored at $-80^{\circ} \mathrm{C}$ until SSH library construction.

\section{Experimental methods}

\section{SSH library construction}

Total RNA was extracted from soybean leaves using Trizol reagent (Takara, Dalian, China). Soybean total RNA quality was checked by $1 \%$ agarose gel electrophoresis. Bands corresponding to $18 \mathrm{~S}$ and $28 \mathrm{~S}$ RNA were clearly visible on the gels (Figure 1), indicating a high level of RNA integrity and purity. Total RNA was reverse-transcribed to cDNA using a SMARTer PCR cDNA Synthesis kit (Clontech/Takara, Mountain View, CA, USA) according to manufacturer instructions. Double-stranded cDNA was obtained using 32 amplification cycles, which was sufficient to achieve the logarithmic amplification phase (Figure 2). SSH was performed on cDNA from 6-BA-treated cotyledon nodes (SSH tester) and non-treated nodes (SSH driver) using a PCR-Select cDNA Subtraction kit (Clontech/Takara) according to manufacturer instructions. Tester cDNA was digested with the restriction endonuclease RsaI and divided into 2 samples; the first sample was ligated to Adaptor 1, and the other was ligated to Adaptor 2R. The samples were stored overnight at $16^{\circ} \mathrm{C}$. An initial hybridization with driver cDNA was performed by incubating each ligated tester cDNA at $98^{\circ} \mathrm{C}$ for $90 \mathrm{~s}$, followed by hybridization at $68^{\circ} \mathrm{C}$ for $9 \mathrm{~h}$. An excess of denatured driver cDNA was added to the resulting SSH mixture for a second hybridization at $68^{\circ} \mathrm{C}$ overnight. The nested polymerase chain reaction (PCR) amplifications were then performed twice. The SSH product was purified, recovered, and cloned into a pMD-T vector at $16^{\circ} \mathrm{C}$ overnight; then, it was transformed into Escherichia coli DH5 $\alpha$ competent cells using a heat shock method. The transformed cells were cultured on agar plates containing 5-bromo-4-chloro-3-indolyl- $\beta$-D-galactopyranoside, isopropyl $\beta$-D-1-thiogalactopyranoside, and ampicillin for blue-white spot screening. White colonies were picked and inoculated into liquid Luria-Bertani medium and incubated over- 
night at $37^{\circ} \mathrm{C}$. A single spot was picked after shaking the culture, and it was subjected to 2 rounds of nested PCR amplifications using primers Primer1F (5'-TCGAGCGGCCGCCCG GGCAGGT-3') and Primer2R (5'-AGCGTGGTCGCGGCCGAGGT-3'). PCRs were performed in $25-\mu \mathrm{L}$ volumes consisting of $2 \mu \mathrm{L}$ culture broth, $2.5 \mu \mathrm{L}$ 10X PCR buffer, $0.5 \mu \mathrm{L} 10$ mM dNTP mix, $0.5 \mu \mathrm{L}$ of each primer, $0.3 \mu \mathrm{L} 5 \mathrm{U} / \mathrm{L}$ LA DNA polymerase, and $18.7 \mu \mathrm{L}$ sterile water. PCR amplification cycles were as follows: $94^{\circ} \mathrm{C}$ for $5 \mathrm{~min} ; 30$ cycles of $94^{\circ} \mathrm{C}$ denaturation for $30 \mathrm{~s}, 68^{\circ} \mathrm{C}$ annealing for $30 \mathrm{~s}$, and $72^{\circ} \mathrm{C}$ extension for $2 \mathrm{~min}$; and a final extension of $72^{\circ} \mathrm{C}$ for $5 \mathrm{~min}$. Colonies that were identified as positive clones were preserved by adding $30 \%$ glycerol and stored at $-80^{\circ} \mathrm{C}$.

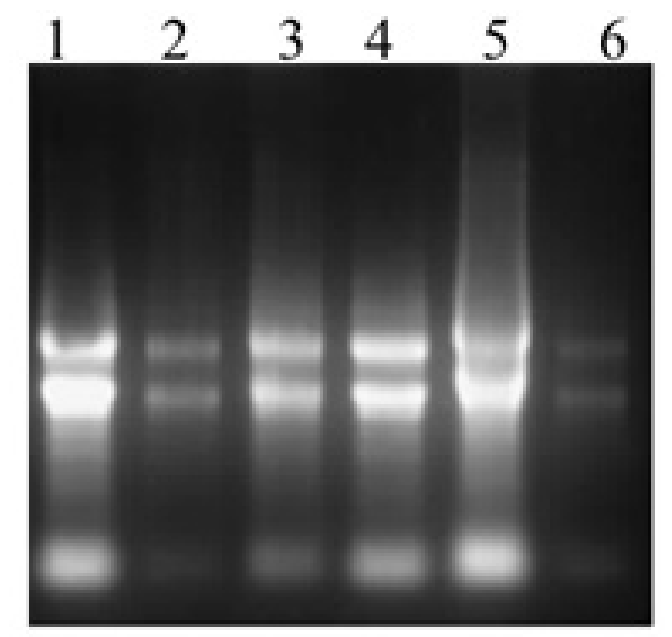

Figure 1. Total RNA extracted from soybean cotyledonary nodes. Lanes 1 to $6=$ total RNA of soybean cotyledonary nodes.

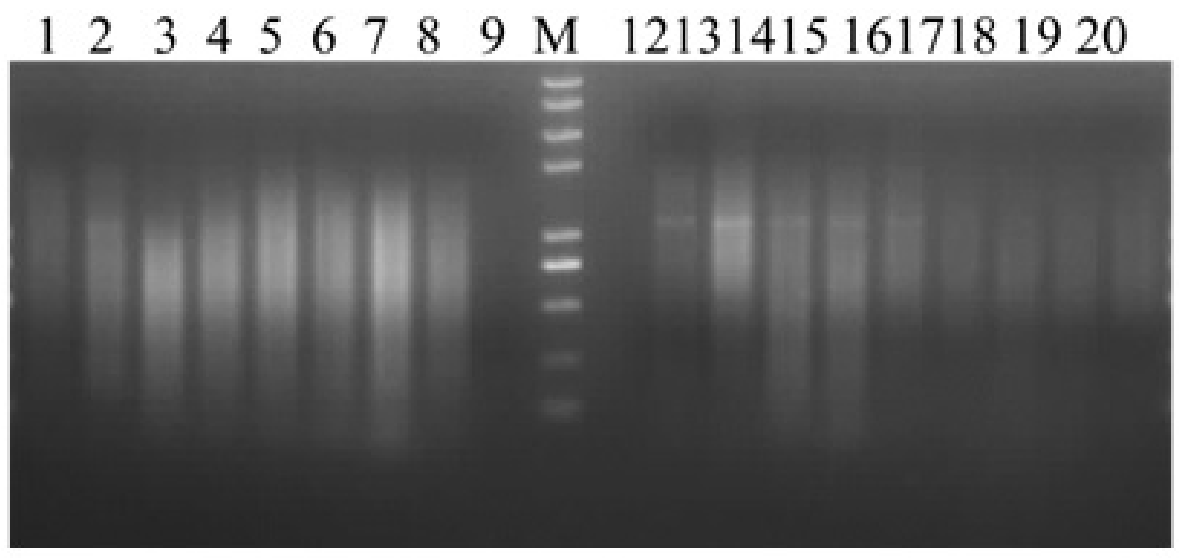

Figure 2. Polymerase chain reaction amplification of tester and driver cDNA. Lane M: DL15000 DNA marker; lanes 1-9: cDNA amplification of tester cDNA with 15, 18, 21, 24, 27, 30, 33, 36, and 39 cycles; lanes 12-20: cDNA amplification of driver cDNA with 15, 18, 21, 24, 27, 30, 33, 36, and 39 cycles. 


\section{DNA sequencing and sequence analysis}

We used real-time reverse transcription (RT)-PCR to confirm the relative expression of 4 differentially expressed genes that were identified in the SSH library. To obtain material for analysis, cotyledon nodes were generated by culturing DN50 seeds on MS medium for 6 days. The cultures were then shaken in liquid MS medium with or without 6-BA, and samples were taken at $1,2,4,6,8,12,24$, and $48 \mathrm{~h}$. Total RNA was extracted with Trizol reagent, reverse-transcribed into cDNA, and stored at $-80^{\circ} \mathrm{C}$ until use.

PCR primers were designed based on sequences in GenBank and are listed in Table 1. A SYBR(R) Ex Script RT-PCR kit (Takara) was used according to manufacturer instructions for the amplification reactions. The soybean housekeeping gene actin 4 was used as an internal reference.

Real-time RT-PCR mixtures comprised $1.6 \mu \mathrm{L}$ first-strand cDNA, $1.6 \mu \mathrm{L}$ upstream and downstream primers, $10 \mu \mathrm{L}$ SYBR qPCR Mix, and $6.8 \mu \mathrm{L}$ deionized water to give a total volume of $20 \mu \mathrm{L}$. PCR amplification cycles were as follows: $95^{\circ} \mathrm{C}$ denaturation for $30 \mathrm{~s}$, followed by 40 cycles of $95^{\circ} \mathrm{C}$ denaturation for $5 \mathrm{~s}, 60^{\circ} \mathrm{C}$ annealing for $20 \mathrm{~s}$, and $72^{\circ} \mathrm{C}$ extension for $20 \mathrm{~s}$. PCRs were repeated 3 times for each sample.

The Opticon Monitor 3.1 software was used to analyze the data and calculate the relative gene expression.

Table 1. Primers used for fluorescence real-time reverse transcription-polymerase chain reaction.

\begin{tabular}{|c|c|c|}
\hline Gene (accession number) & Amplification size & Oligonucleotide sequence $5^{\prime} \rightarrow 3^{\prime}$ \\
\hline Actin 4 (AF049106) & 214 bp & $\begin{array}{l}\text { F: GTGTCAGCCATACTGTCCCCATTT } \\
\text { R: GTTTCAAGCTCTTGCTCGTAATCA }\end{array}$ \\
\hline 1F: Glycine max acid phosphatase (NM_001249251.1) & $126 \mathrm{bp}$ & $\begin{array}{l}\text { F: TCGACCTTGTATGATGAATGGGTT } \\
\text { R: TTGCTTCTGTTACGGCCTGTTTG }\end{array}$ \\
\hline 2F: Glycine max vspA (M76981.1) & 148 bp & $\begin{array}{l}\text { F: TCGACCTTGTATGATGAATGGGTT } \\
\text { R: TTGCTTCTGTTACGGCCTGTTTG }\end{array}$ \\
\hline 3F: 16S ribosomal (AF537102.1) & 102 bp & $\begin{array}{l}\text { F: TTATGCTAGTGAACGCGAAGTCC } \\
\text { R: GGTTTCATTAAATTCCTCCACCC }\end{array}$ \\
\hline 4F: Glycine max porphobilinogen deaminase (NM_001253959.2) & $125 \mathrm{bp}$ & $\begin{array}{l}\text { F: GCTTAGTAGTGCCAATGCAAGTT } \\
\text { R: AGCGATGGAAGATCACCGAATAT }\end{array}$ \\
\hline 3R: Glycine max MET2 (NM001248577.1) & $82 \mathrm{bp}$ & $\begin{array}{l}\text { F: TGTATGTGATTGTTGTGACTCGTTC } \\
\text { R: AGTTACCACCGCAGCAAGACATTTT }\end{array}$ \\
\hline
\end{tabular}

\section{RESULTS}

\section{Analysis of PCR amplifications after subtractive hybridization}

PCR amplification of mixtures obtained following 2 rounds of subtractive hybridization yielded uniform, smeared DNA fragments of 200-1500 bp. The average fragment length was between 400 and 700 bp (Figure 3).

\section{PCR amplification of inserted fragments in the SSH cDNA library}

The cDNA fragments that were generated from the SSH cDNA library were transformed into $E$. coli $\mathrm{DH} 5 \alpha$. According to the blue and white spot screening, 917 positive clones were randomly chosen. PCR amplification confirmed that the length of most inserted cloned fragments was between 100 and $750 \mathrm{bp}$, with an average length of about $500 \mathrm{bp}$ (Figure 4). 


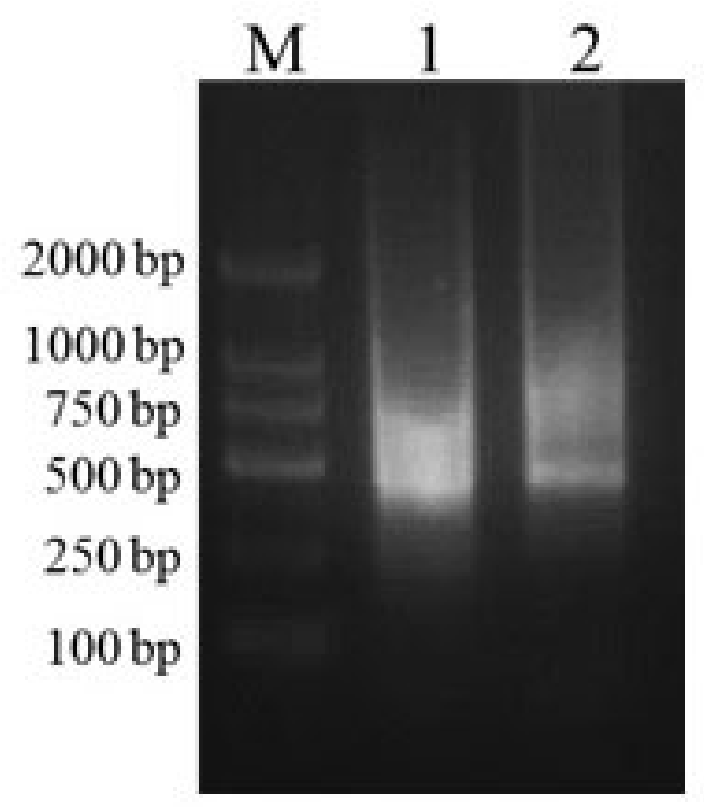

Figure 3. PCR hybridization products after subtraction. Lane $M=$ DL2000 DNA marker; lane $1=$ tester PCR products after subtraction; lane $2=$ driver PCR products after subtraction.

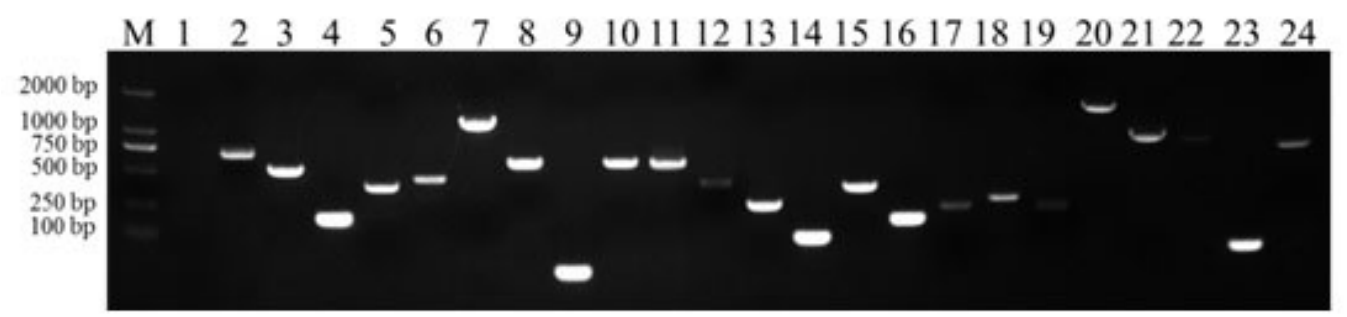

Figure 4. Screening of the inserts in clones of the suppression subtractive hybridization (SSH) cDNA library. Lane $M=$ DL2000 DNA marker; lanes 1-24 = inserts.

\section{Expressed sequence tag (EST) sequences and homology search results}

A total of 917 clones were randomly obtained and sequenced, and $411(44.8 \%)$ of the resulting ESTs were high quality. These sequences were searched against the GenBank database using the nucleotide and translated nucleotide Basic Local Alignment Search Tools (BLAST). The sequences were matched to annotated genes involved in signal transduction, glucose and protein synthesis and metabolism, light and leaf morphogenesis, regulation of apoptosis, cell defense, cell wall differentiation, and a variety of hormone and cytokinin-mediated signaling pathways (Figure 5 and Table 2). 


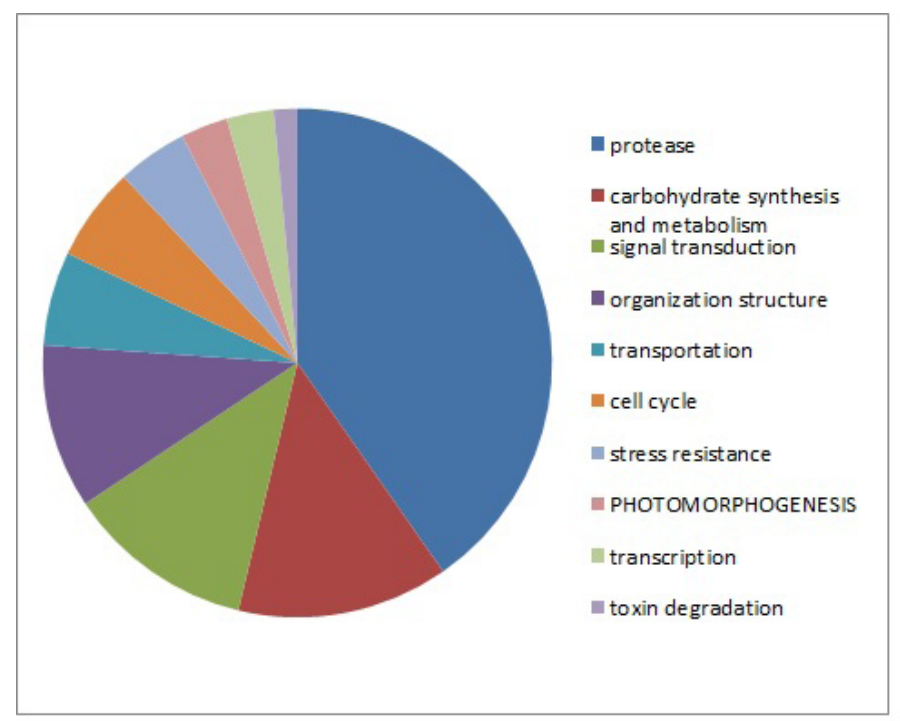

Figure 5. Classification of the expressed sequence tags in the SSH library.

Table 2. Similarity between expressed sequence tags in the suppression subtractive hybridization library and genes in GenBank.

\begin{tabular}{|c|c|c|c|}
\hline Gene No. & Accession No. & Gene homology & Gene name \\
\hline F14_12_RV_M_D02_1110082547J & NM_001251530.2 & $\begin{array}{l}\text { Glycine max } 28-\mathrm{kDa} \text { protein } \\
\text { (VSPA), mRNA }\end{array}$ & VSPA \\
\hline F14_19_21_RV_M_A11_1110082616J & AB118810.1 & $\begin{array}{l}\text { Phaseolus vulgaris PSP gene for } \\
\text { pod storage protein, complete CDS }\end{array}$ & $P S P$ \\
\hline F14_19_32_RV_M_C12_1110082627J & AF537102.1 & $\begin{array}{l}\text { 16S ribosomal RNA gene, partial } \\
\text { sequence }\end{array}$ & $16 \mathrm{~S}$ ribosomal \\
\hline F14_57_RV_M_A08_1110082592J & NM_001249251.1 & $\begin{array}{l}\text { Glycine max acid phosphatase } \\
\text { (LOC547669) }\end{array}$ & acid phosphatase \\
\hline F173_RV_M_H02_1111083379J & DQ455592.1 & $\begin{array}{l}\text { Phaseolus vulgaris SGT1-like protein } \\
\text { mRNA, partial CDS }\end{array}$ & $S G T 1$ \\
\hline F180_RV_M_B11_1111083386J & AB242267.2 & $\begin{array}{l}\text { Sesbania rostrata } S r G L U 5 \text { mRNA } \\
\text { for beta-1,3-glucanase }\end{array}$ & $\beta$-1,3-glucanase \\
\hline F4_120_RV_M_B01_1111080367J & NM_001255715.2 & $\begin{array}{l}\text { Glycine max porphobilinogen deaminase, } \\
\text { chloroplastic-like }\end{array}$ & $P B G D$ \\
\hline F4_81_RV_M_A11_1111080328J & JN033738.2 & $\begin{array}{l}\text { Chilo suppressalis serine protease } \\
\text { inhibitor } 012 \text { mRNA }\end{array}$ & serine protease inhibitors \\
\hline F4_91_RV_M_C10_1111080338J & DQ317523.1 & $\begin{array}{l}\text { Glycine max cultivar PI } 437654 \text { chloroplast, } \\
\text { complete genome }\end{array}$ & chloroplast \\
\hline F_315_RV_M_B03_1111083667J & EF464674.1 & $\begin{array}{l}\text { Gossypium hirsutum GDP-mannose } \\
\text { pyrophosphorylase mRNA, partial CDS }\end{array}$ & $G M P P B$ \\
\hline F_396_RV_M_B11_1111083748J & JQ711538.1 & $\begin{array}{l}\text { Olea europaea xylose isomerase mRNA, } \\
\text { partial CDS }\end{array}$ & xylose isomerase \\
\hline F_567_RV_M_B08_1111083919J & AJ223716.1 & $\begin{array}{l}\text { Squalus acanthias mRNA for } s g k-2 \\
\text { serine-threonine protein kinase }\end{array}$ & $\begin{array}{l}\text { serine-threonine protein } \\
\text { kinase }\end{array}$ \\
\hline F_576_RV_M_C09_1111083928J & NM_001250642.1 & Glycine max catalase (CAT4), mRNA & CAT4 \\
\hline 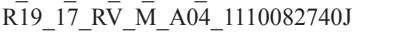 & NM_001251763.1 & Glycine max lipoxygenase & $L O X B 1$ \\
\hline 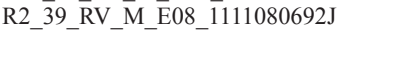 & EU683445.1 & $\begin{array}{l}\text { Malpighia glabra L-galactono-1, -lactone } \\
\text { dehydrogenase mRNA, complete CDS }\end{array}$ & $\begin{array}{l}\text { L-galactono-1,4-lactone } \\
\text { dehydrogenase }\end{array}$ \\
\hline R400_RV_M_B04_1111083521J & U39567.1 & $\begin{array}{l}\text { Glycine max ribulose-1,5-bisphosphate } \\
\text { carboxylase small subunit mRNA }\end{array}$ & $\begin{array}{l}\text { ribulose-1,5-bisphosphate } \\
\text { carboxylase }\end{array}$ \\
\hline R4_23_RV_M_B06_1111080445J & NM_001248577.1 & Glycine max metallothionein type 2 & MET2 \\
\hline R4_36_RV_M_G03_1111080458J & J05208.1 & $\begin{array}{l}\text { Soybean (Glycine max) proline-rich cell } \\
\text { wall protein gene }\end{array}$ & $S b P R P 2$ \\
\hline
\end{tabular}




\section{Relative expression analysis of candidate cDNA fragments by real-time quantitative PCR}

The results of the real-time RT-PCR analysis of 4 genes that were differentially expressed between the 6-BA treatment and control conditions in cotyledon nodes are shown in Figure 6. The expression of the acid phosphatase $(A S P)$ gene was steady for the first $4 \mathrm{~h}$, increased at $6 \mathrm{~h}$, and then decreased sharply after $12 \mathrm{~h}$, indicating that this gene is negatively regulated by 6-BA. The VSPA gene expression was stable for the first $6 \mathrm{~h}$, rapidly increased at $8 \mathrm{~h}$, reached a peak at $12 \mathrm{~h}$, and then decreased rapidly. The expression of the $16 \mathrm{~S}$ ribosomal gene following 6-BA treatment stabilized before $8 \mathrm{~h}$ and then reached its highest expression level at $12 \mathrm{~h}$, suggesting that the $16 \mathrm{~S}$ ribosomal gene may play a downstream role in the cytokinin pathway. The porphobilinogen deaminase gene expression increased suddenly at $2 \mathrm{~h}$, when it reached its peak at $4 \mathrm{~h}$, and then it stabilized, suggesting that this gene may play an upstream role in the cytokinin pathway (Figure 6).

A

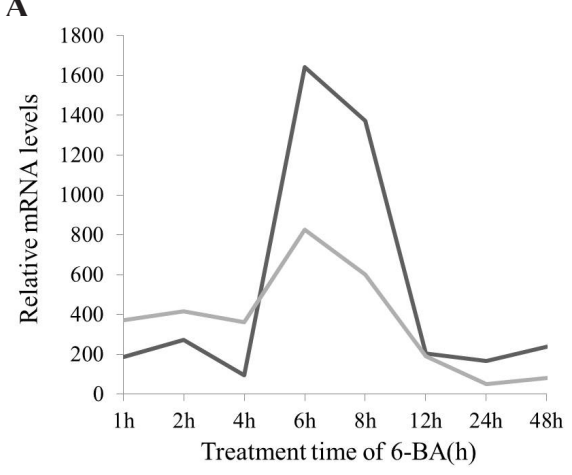

C

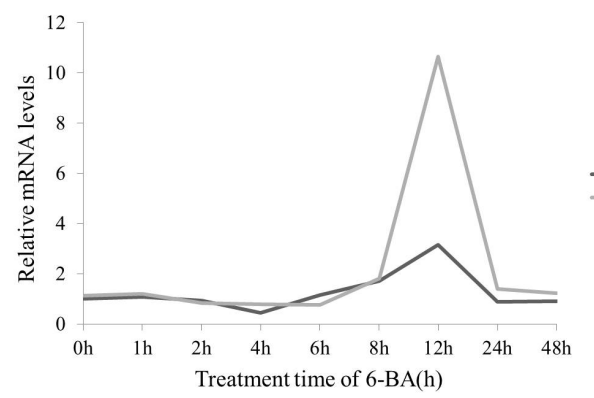

B

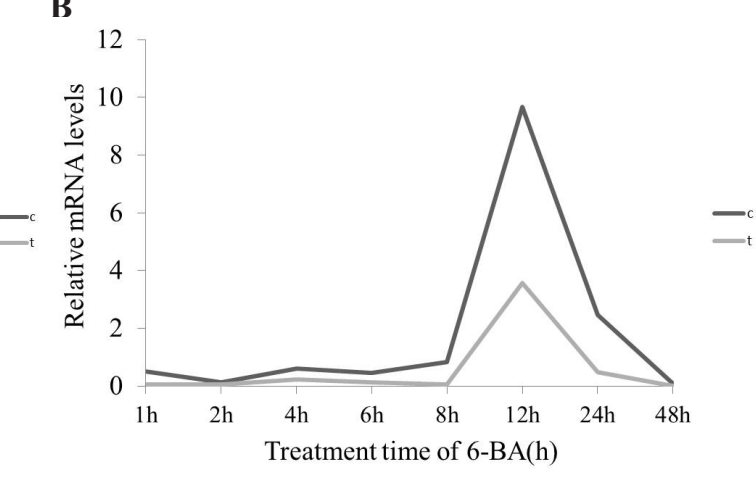

D

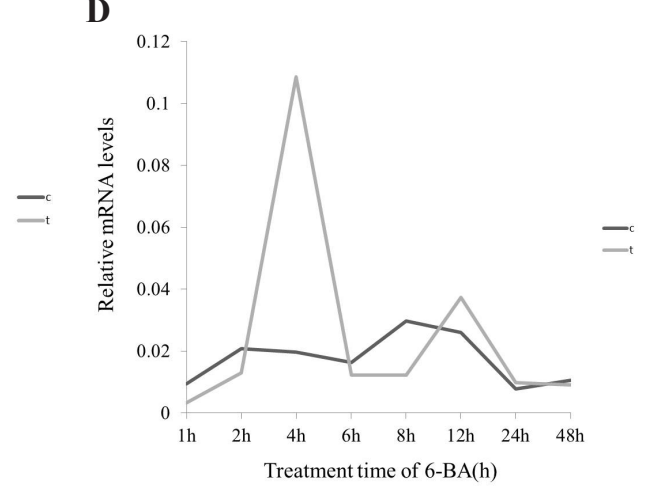

Figure 6. Expression of genes with 6-benzyladenine (6-BA) treatment. A. Expression of Glycine max acid phosphatase with 6-BA treatment. B. Expression of VSPA with 6-BA treatment. C. Expression of 16S ribosomal with 6-BA treatment. D. Expression of Glycine max porphobilinogen deaminase with 6-BA treatment. c = control; $\mathrm{t}=$ treatment. 


\section{DISCUSSION}

Our study is the first reported construction of a cDNA library and isolation of differentially expressed genes from cytokinin-induced soybean cotyledonary nodes using SSH. Our data should contribute to research into soybean organogenesis regeneration pathways and can be used to screen soybean regeneration candidate genes.

The plant regeneration process generally involves 3 main steps (Huang et al., 2007): 1) induction by a hormone, 2) specific cell division, and 3) adventitious bud regeneration. Cytokinin, the hormone that is most frequently involved in the natural formation of adventitious buds, plays a vital role in root and stem cell division and many other plant developmental processes (Howell et al., 2003). During adventitious bud induction, cytokinin can act alone or in synergy with auxin. To respond to cytokinin, cells require receptors for signal perception (Kakimoto, 1998; Stock et al., 2000; Lohrmann and Harter, 2002; Riefler et al., 2006).

Cytokinins can cause cell division, induce the formation of buds, and promote bud growth and development. Cytokinins cause biological effects by signal transduction. The functions of the receptors of cytokinin signaling pathways, such as CRE1, CKI1, AHP, and ARR, have been investigated (Haberer and Kieber, 2002; Hutchison and Kieber, 2002; Ferreira and Kieber, 2005). Skoog and Miller proposed the auxin-cytokinin hypothesis in plant morphogenesis, in which an appropriate cytokinin and auxin play a key role in the process of growth after the formation of plant morphogenesis and roots. In this hypothesis, cytokinins are important in the regulation of plant morphogenesis (Kakimoto, 1996; Hwang and Sheen, 2001; Che et al., 2002; Sun et al., 2003).

Soybean contains 2 vegetative storage proteins (VSPs) that function as temporary storage reserves and are also closely related to plant ASPs from the haloacid dehalogenase superfamily. When ASP is reduced, VSPs can prevent the storage protein from functioning (Leelapon et al., 2004).

Some genes in the library have been studied. Differences in the quantity and cleavage efficiency of reactive oxygen species (ROS) are major causal factors in observed variations in the ability of plants to regenerate (Cutler et al., 1991). Papadakis and Roubelakis-Angelakis (2002) found that protoplast totipotency was positively correlated with antioxidant activity properties of cells in tobacco and grape, and negative correlations were observed between totipotency and ROS levels in the medium. Zhang et al. (2010) found that the amount of $\mathrm{H}_{2} \mathrm{O}_{2}$ in immature larch embryos increased and then decreased during somatic embryogenesis, thereby maintaining their volatility. They also reported that catalase activity was stable during prophase and elevated in middle and later periods, and then it decreased. Superoxide dismutase activity increased during prophase, and then it decreased rapidly, whereas APX activity fluctuated during prophase and increased during anaphase. During callus differentiation in strawberry tissue culture, Tian et al. (2003) observed that superoxide dismutase activity first increased and then decreased, catalase activity continually decreased, and peroxidase activity first decreased and then increased. They also reported that high $\mathrm{O}_{2}^{-}$and low $\mathrm{H}_{2} \mathrm{O}_{2}$ content were related to organ formation. Superoxide dismutase activity is usually detected in callus only during regeneration, and exogenous $\mathrm{H}_{2} \mathrm{O}_{2}$ can promote bud regeneration in the callus (Tian et al., 2003). Thus, oxidative stress can induce the synthesis of the antioxidant enzyme, thereby promoting regeneration. On the other hand, the occurrence of oxidative stress in cells changes the cell membrane permeability, leading to cell death (Ye et al., 2012).

Ribulose 1,5-bisphosphate carboxylase/oxygenase (Rubisco) is an important $\mathrm{CO}_{2}$ - 
fixing enzyme in plant photosynthesis. It is also involved in plant photorespiration metabolic pathways, although its oxygenation of ribulose biphosphate leads to net photosynthetic efficiency losses of up to 50\% (Lundqvist and Schneider, 1991; Xiong et al., 2003; Ashida et al., 2005). Therefore, the regulation of Rubisco activity is important to improve photosynthetic efficiency. Jiang et al. (2006) studied the effect of 6-BA and abscisic acid (ABA) on the decline of leaf photosynthetic function in different genotypes of tobacco varieties NC89 and JY H. They found that 6-BA treatment significantly improved the instantaneous photosynthetic rate, chlorophyll content, chloroplast electron transport activity, and Rubisco activity in tobacco leaves, and it prolonged photosynthetic function. It also improved the ratio of photosynthetic electron transport to carbon assimilation, thereby delaying photosynthetic function decline. The opposite results were obtained upon ABA treatment.

BLAST of other ESTs in the National Center for Biotechnology Information database indicated that genes that were induced by 6-BA could be functionally classified into categories associated with hormone signal transduction pathways; seed germination and flowering time; negative regulation of programmed cell death; leaf senescence; pollen tube growth; anabolic metabolism of glucose, proteins, and other macromolecules; photosynthesis; ribosomes; transport proteins; and catalase and acid phosphatase activity. We also uncovered many genes that were related to stress, such as cold, heat, drought, high salt, and mechanical damage, and some genes of unknown function. These genes were differentially expressed in the presence of cytokinin, indicating the importance of future studies that focus on soybean regeneration genes.

\section{ACKNOWLEDGMENTS}

Research supported by the Natural Science Foundation of China (grant \#31071438), the Natural Science Foundation of Heilongjiang Province of China (\#ZD201117), and the Key Project of Heilongjiang Province Department of Education (\#12531z001).

\section{REFERENCES}

Ashida H, Danchin A and Yokota A (2005). Was photosynthetic RuBisCO recruited by acquisitive evolution from RuBisCO like proteins involved in sulfur metabolism? Res. Microbiol. 156: 611-618.

Banno H, Ikeda Y, Niu QW and Chua NH (2001). Overexpression of Arabidopsis ESR1 induces initiation of shoot regeneration. Plant Cell 13: 2609-2618.

Che P, Gingerich DJ, Lall S and Howell SH (2002). Global and hormone-induced gene expression changes during shoot development in Arabidopsis. Plant Cell 14: 2771-2785.

Cutler AJ, Saleem M and Wang H (1991). Cereal protoplast recalcitrance. In Vitro Cell Dev. Biol. 27: 104-111.

Ferreira FJ and Kieber JJ (2005). Cytokinin signaling. Curr. Opin. Plant Biol. 8: 518-525.

Haberer G and Kieber JJ (2002). Cytokinins. New insights into a classic phytohormone. Plant Physiol. 128: 354-362.

Hinchee MAW, Conner-Ward DV, Newell CA, McDonnell RE, et al. (1988). Production of transgenic soybean plants using Agrobacterium-mediated DNA transfer. Nat. Biotechnol. 6: 915-922.

Howell SH, Lall S and Che P (2003). Cytokinins and shoot development. Trends Plant Sci. 8: 453-459.

Huang J, Shen HL, Liu CL and Li YH (2007). Review on molecular regulation of in vitro shoot regeneration of plants. $Y i$ Chuan 29: 528-536.

Hutchison CE and Kieber JJ (2002). Cytokinin signaling in Arabidopsis. Plant Cell 14: S47-S59.

Hwang I and Sheen J (2001). Two-component circuitry in Arabidopsis cytokinin signal transduction. Nature 413: 383-389.

Ikeda Y, Banno H, Niu QW, Howell SH, et al. (2006). The ENHANCER OF SHOOT REGENERATION 2 gene in Arabidopsis regulates CUP-SHAPED COTYLEDON 1 at the transcriptional level and controls cotyledon development. Plant Cell Physiol. 47: 1443-1456.

Jiang L, Kong XW and Zhang RX (2006). Effects of 6-benzyladenine and abscisic acid on the photosynthetic function 
decline in tobacco. J. Nanjing Agr. Univ. 29: 127-130.

Kakimoto T (1996). CKI1, a histidine kinase homolog implicated in cytokinin signal transduction. Science 274: 982-985. Kakimoto T (1998). Cytokinin signaling. Curr. Opin. Plant Biol. 1: 399-403.

Komatsuda T, Annaka T and Oka S (1993). Genetic mapping of a quantitative trait locus (QTL) that enhances the shoot differentiation rate in Hordeum vulgare L. Theor. Appl. Genet. 86: 713-720.

Leelapon O, Sarath G and Staswick PE (2004). A single amino acid substitution in soybean VSP $\alpha$ increases its acid phosphatase activity nearly 20-fold. Planta 219: 1071-1079.

Leibfried A, To JP, Busch W, Stehling S, et al. (2005). WUSCHEL controls meristem function by direct regulation of cytokinin-inducible response regulators. Nature 438: 1172-1175.

$\mathrm{Li} \mathrm{Z}$ and Komatsu S (2000). Molecular cloning and characterization of calreticulin, a calcium-binding protein involved in the regeneration of rice cultured suspension cells. Eur. J. Biochem. 267: 737-745.

Lohrmann J and Harter K (2002). Plant two-component signaling systems and the role of response regulators. Plant Physiol. 128: 363-369.

Low RK, Prakash AP, Swarup SS, Goh CJ, et al. (2001). A differentially expressed bZIP gene is associated with adventitious shoot regeneration in leaf cultures of Paulownia kawakamii. Plant Cell Rep. 20: 696-700.

Lundqvist T and Schneider G (1991). Crystal structure of activated ribulose-1,5-bisphosphate carboxylase complexed with its substrate, ribulose-1,5-bisphosphate. J. Biol. Chem. 266: 12604-12611.

McCabe DE, Swain WF, Martinell BJ and Christou P (1988). Stable transformation of soybean (Glycine max) by particle acceleration. Nat. Biotechnol. 6: 923-926.

Papadakis AK and Roubelakis-Angelakis KA (2002). Oxidative stress could be responsible for the recalcitrance of plant protoplasts. Plant Physiol. Biochem. 40: 549-559.

Riefler M, Novak O, Strnad M and Schmülling T (2006). Arabidopsis cytokinin receptor mutants reveal functions in shoot growth, leaf senescence, seed size, germination, root development, and cytokinin metabolism. Plant Cell 18: 40-54.

Stock AM, Robinson VL and Goudreau PN (2000). Two-component signal transduction. Annu. Rev. Biochem. 69: 183215.

Sun J, Niu QW, Tarkowski P, Zheng B, et al. (2003). The Arabidopsis AtIPT8/PGA22 gene encodes an isopentenyl transferase that is involved in de novo cytokinin biosynthesis. Plant Physiol. 131: 167-176.

Tian M, Gu Q and Zhu MY (2003). The involvement of hydrogen peroxide and antioxidant enzymes in the process of shoot organogenesis of strawberry callus. Plant Sci. 165: 701-707.

Xiong XR, Chen WM, Feng SY, Guo MX, et al. (2003). Simulation on botanic Rubisco active center. Chinese J. Biochem. Mol. Biol. 19: 493-498.

Ye XG, She MY, Wang K, Du LP, et al. (2012). Identification, cloning, and potential application of genes related to somatic embryogenesis in plant tissue culture. Acta Agron. Sinica 38: 191-201.

Zakizadeh H, Stummann BM, Lütken H and Müller R (2010). Isolation and characterization of four somatic embryogenesis receptor-like kinase (RhSERK) genes from miniature potted rose (Rosa hybrida cv. Linda). Plant Cell Tiss. Organ Cult. 101: 331-338.

Zhang SG, Han SY, Yang WH, Wei HL, et al. (2010). Changes in $\mathrm{H}_{2} \mathrm{O}_{2}$ content and antioxidant enzyme gene expression during the somatic embryogenesis of Larix leptolepis. Plant Cell Tiss. Organ Cult. 100: 21-29.

Zubko E, Adams CJ, Macháèková I, Malbeck J, et al. (2002). Activation tagging identifies a gene from Petunia hybrida responsible for the production of active cytokinins in plants. Plant J. 29: 797-808. 